Noviyanti, A. R., Hastiawan, I Akrajas

Ali Umar, A.A., Diana Eddy, D. R.,

Abdilah, $G$.
Pengaruh Surfaktan Biner Cetil Trimetil Amonium Bromida (CTAB) - Hexametilen Triamin (HMT) pada Pembentukan Perak Nanorods menggunakan Katalis Natrium Hidroksida

\title{
Pengaruh Surfaktan Biner Cetil Trimetil Amonium Bromida (CTAB)- Hexametilen Triamin (HMT) pada Pembentukan Perak Nanorods menggunakan Katalis Natrium Hidroksida
}

\author{
Atiek Rostika Noviyanti ${ }^{1}$, Iwan Hastiawan ${ }^{1}$, Akrajas Ali Umar ${ }^{2}$, Diana Rakhmawaty ${ }^{1}$ \\ Eddy, Gani Abdilah ${ }^{1}$ \\ ${ }^{1}$ Laboratorium Kimia Fisik dan Anorganik, Departemen Kimia Fakultas Matematika dan \\ IImu Pengetahuan Alam, Universitas Padjadjaran \\ Jl. Raya Bandung-Sumedang Km. 21 Jatinangor, Sumedang Indonesia, 463532 \\ 2) Makmal Organic Printed Electronic Laboratory (OPEL), Institute of Microengineering \\ and Nanoelectronic (IMEN), Universitas Kebangsaan Malaysia (UKM), Bangi, Selangor \\ 43600, Malaysia \\ Email: atiek.noviyanti@unpad.ac.id
}

\begin{abstract}
Nanoparticles have different physical properties and more interesting than that of bulk material. Nanoparticles are highly preferred for applications in various technologies as a catalyst, the raw material of electronic components, and as an antimicrobial agent. The aim of the research is synthesize of silver nanorods. The effect of a binary surfactant CTAB-HMT on the morphology and homogeneity were investigated using UV/Vis spectrophotometer, TEM, and XRD. Base on the UV/Vis spectra and TEM morphology, silver nanoparticles have two types, spherical and rods shapes. The best product of nanorods was obtained at the composition of CTAB $0.15 \mathrm{M}:$ HMT $0.15 \mathrm{M}$. The structure of nanorods obtained were face center cubic (fcc).
\end{abstract}

Keywords: CTAB, FCC, HMT, silver nanorods

\section{PENDAHULUAN}

Penelitian material nano terus dilakukan baik oleh para peneliti maupun pengguna di kalangan dunia industri, salah satunya adalah metode sintesisnya. Sintesis partikel nano merupakan suatu proses pembuatan partikel dengan ukuran kurang dari $100 \mathrm{~nm}$ sehingga mengubah sifat atau fungsinya (Brioude et al. , 2005).

Material partikel nano memiliki sifat fisik yang berbeda dibandingkan dengan material ruahnya. Hal ini pula yang menjadikan partikel nano sangat disukai untuk diaplikasikan pada berbagai bidang teknologi (Gong et al., 2007). Dua faktor utama yang menyebabkan partikel nano memiliki beberapa kelebihan diantranya karena efek permukaan dan efek kuantum. Faktorfaktor ini mempengaruhi reaktivitas kimia dari suatu material serta sifat mekanik, optik, listrik serta magnetic juga bisa efektif membunuh bakteri (Burrell et al., 1999), bisa mendeteksi biomolekuler pada chip sensor (Moores \& Goettmann, 2006), antibiotik (Percival et al., 2001), 
Noviyanti, A. R., Hastiawan, I Akrajas

Ali Umar, A.A., Diana Eddy, D. R.

Abdilah, G.
Pengaruh Surfaktan Biner Cetil Trimetil Amonium Bromida (CTAB)-Hexametilen Triamin (HMT) pada Pembentukan Perak Nanorods menggunakan Katalis Natrium Hidroksida

serta memiliki konduktivitas dan efek katalitik yang baik, (J.M. Köhler et al., 2008). Salah satu partikel nano yang banyak digunakan adalah perak.

Partikel nano perak yang telah dimodifikasi digunakan dalam berbagai bidang seperti untuk bahan tekstil, semikonduktor serta untuk bahan baku pembuatan komposit nano (P.D. Cozzoli et al., 2004). Dalam bidang kesehatan partikel nano perak digunakan sebagai pelapis alat medis dan bahan yang digunakan dalam bidang bedah, anestesiologi, kardiologi, urologi (Wijnhoven et al., 2009) dan untuk pencitraan sel kanker serta pengobatan sel (Elechiguerra et al., 2005).

Tantangan terbesar untuk produksi partikel nano perak pada saat ini adalah metode produksi dalam skala besar, dengan waktu relatif singkat dan biaya yang murah. Metode yang dikembangkan adalah sintesis menggunakan air sebagai medianya yang lebih dikenal dengan metode mediasi pembenihan (seed mediated growth). Metode ini dipilih sebagai metode sintesis pada penelitian ini karena selain dapat mengontrol bentuk, ukuran dan morfologi partikelnya, juga memungkinkan membuat partikel dalam jumlah besar (Abdulah dkk, 2008).

Sintesis partikel nano perak dengan metode mediasi pembenihan pada umumnya menggunakan surfaktan atau polimer yang membentuk susunan teratur (self-assembly) pada permukaan partikel nano perak. Bagian surfaktan atau polimer yang hidrofob langsung teradsorpsi pada permukaan partikel nano dan bagian hidrofilnya berada pada bulk larutan. Bahan organik tersebut (surfaktan dan polimer) dapat mengkontrol kecepatan reduksi dan agregasi partikel nano perak. Reaksi yang terjadi sebagai berikut:

$\mathrm{M}^{\mathrm{n}+}+$ pereduksi $\longrightarrow$ partikel nano

Faktor yang mempengaruhi sintesis partikel nano antara lain konsentrasi reaktan, molekul pelapis (capping reagent), suhu, dan pengadukan.

Untuk menyintesis partikel nano perak dengan ukuran dan bentuk yang diinginkan dilakukan deaktivasi permukaan partikel koloid yang telah dibuat. Jika tidak dideaktivasi maka ukuran partikel koloid bisa akan terus bertambah selama masih ada atom prekursor di dalam larutan. Salah satu cara deaktivasi yang banyak dilakukan adalah dengan menggunakan zat aktif permukaan atau dikenal dengan surfaktan (surface active agent). Bentuk partikel nano perak yang disintesis pada penelitian ini berbentuk batang (silver nanorods). Spektrum ultra violet partikel nano perak batang pada umumnya ditandai dengan munculnya transversal surface plasmon resonance (TSPR) dan longitudinal surface plasmon resonance (LSPR). Sementara pada partikel nano perak yang berbentuk bola, yang muncul hanya puncak TSPR. Adanya LSPR ini membuat perak nanorods dapat digunakan untuk pengobatan penyakit kanker (Brioude et al. , 2005).

Berdasarkan latar belakang di atas, penelitian bertujuan memperoleh partikel nano perak bentuk batang dengan cara mudah dengan hasil yang melimpah. Mengontrol pembentukan partikel nano perak bentuk batang selama proses sintesis berlangsung merupakan langkah penting untuk menghasilkan produk sesuai. Selain itu pemilihan sufraktan sangat menentukan bentuk perak nano yang dihasilkan. 
Noviyanti, A. R., Hastiawan, I Akrajas

Ali Umar, A.A., Diana Eddy, D. R.,

Abdilah, G.
Pengaruh Surfaktan Biner Cetil Trimetil Amonium Bromida (CTAB)-Hexametilen Triamin (HMT) pada Pembentukan Perak Nanorods menggunakan Katalis Natrium Hidroksida

Pada penelitian ini dipilih surfaktan biner setil trimetilammonium bromide (CTAB) heksametilentetraamin (HMT) dengan katalis natrium hidroksida dalam medium pelarut air. Pengaruh konsentrasi surfaktan CTAB-HMT terhadap penumbuhan perak nanorods.

\section{METODE PENELITIAN}

Penelitian ini dilakukan dalam beberapa tahapan diantaranya, pembuatan larutan induk, pembuatan larutan penumbuh dan sintesis perak nanorods dengan variasi konsentrasi $\mathrm{NaOH}$, variasi surfaktan dan karakterisasi produk.

Larutan induk (seed) disiapkan dari larutan $\mathrm{AgNO}_{3} \quad 0,01 \mathrm{M}$ sebanyak 0,5 mL dan $\mathrm{NaBH}_{4}$ 0,01 M sebanyak 0,5 mL yang campurannya kemudian dimasukan ke dalam botol dan diaduk sampai homogen. Ke dalam campuran ditambahkan $20 \mathrm{~mL}$ air deionisasi dan $0,5 \mathrm{~mL}$ natrium borohidrida 0,1 M kemudian dikocok lagi sampai homogen. Campuran didiamkan selama 60 menit dan siap untuk ditumbuhkan.

Sementara itu larutan penumbuh (growing) dibuat dengan mencampurkan $10 \mathrm{~mL}$ larutan CTAB 0,1 M dengan $10 \mathrm{~mL}$ larutan HMT 0,1 M kemudian diaduk sampai homogen. Secara bertahap ke dalam larutan tersebut ditambahkan $0,5 \mathrm{~mL}$ perak nitrat $0,01 \mathrm{M}, 0,2 \mathrm{~mL}$ larutan asam askorbat $0,1 \mathrm{M}$ dan $0,5 \mathrm{~mL}$ larutan natrium hidroksida $0,1 \mathrm{M}$ sambil diaduk sampai homogen. Setelah larutan penumbuh siap dipreparasi, sebanyak $0,5 \mathrm{~mL}$ larutan induk ditambahkan ke dalamnya sambil diaduk sampai campuran homogen.

Untuk mengetahui pengaruh konsentrasi katalis $\mathrm{NaOH}$ pengaruh surfaktan (HTM dan CTAB) maka dibuat beberapa variasi kondisi sintesis seperti ditunjukkan dalam Tabel 1.

Tabel 1. Beberapa variasi kondisi sintesis perak nanorods untuk mengetahui pengaruh katalis $\mathrm{NaOH}$ dan pengaruh surfaktan HMT dan CTAB terhadap struktur dan morfologinya.

\begin{tabular}{lcccc}
\hline & $\begin{array}{c}\text { Larutan induk } \\
\left(\mathrm{AgNO}_{3}+\mathrm{NaBH}_{4}\right)\end{array}$ & \multicolumn{3}{c}{ Lautan Penumbuh } \\
& $\begin{array}{c}\mathrm{NaOH} \\
0,1 \mathrm{M} \\
(\mathrm{mL})\end{array}$ & $\begin{array}{c}\text { HMT 10 } \\
\mathrm{mL}(\mathrm{M})\end{array}$ & $\begin{array}{c}\text { CTAB 10 } \\
\mathrm{mL}(\mathrm{M})\end{array}$ \\
\hline Sampel 1 & $0,5 \mathrm{~mL}$ & 0,5 & 0,1 & 0,1 \\
Sampel 2 & $0,5 \mathrm{~mL}$ & 1 & 0,1 & 0,1 \\
Sampel 3 & $0,5 \mathrm{~mL}$ & 2 & 0,1 & 0,1 \\
Sampel 4 & $0,5 \mathrm{~mL}$ & 0,5 & 0,05 & 0,05 \\
Sampel 5 & $0,5 \mathrm{~mL}$ & 0,5 & 0.1 & 0,1 \\
Sampel 6 & $0,5 \mathrm{~mL}$ & 0,5 & 0,15 & 0,15 \\
Sampel 7 & $0,5 \mathrm{~mL}$ & 0,5 & 0,2 & 0,2 \\
\hline
\end{tabular}


Noviyanti, A. R., Hastiawan, I Akrajas

Ali Umar, A.A., Diana Eddy, D. R.,

Abdilah, G.
Pengaruh Surfaktan Biner Cetil Trimetil Amonium Bromida (CTAB)-Hexametilen Triamin (HMT) pada Pembentukan Perak Nanorods menggunakan Katalis Natrium Hidroksida

Setelah terjadi perubahan warna campuran larutan, serapan sampel diukur dengan menggunakan larutan campuran siap dikarakterisasi dengan menggunakan spektrofotometer UV (UV-vis Elmer lambda 900 Perkin) Pengukuran serapan larutan dengan spektrofotometer Uv-vis dilakukan untuk memastikan terbentuknya partikel perak nanorods. Kondisi optimum pertumbuhan perak nanorods diamati dengan mencari serapan maksimum pada interval panjang gelombang 300 - $900 \mathrm{~nm}$. Sampel yang masih segar dimasukan ke dalam tabung sentrifuge ( EBA 21 Hettich Zentrifuge), kemudian diputar dengan kecepatan 6000 rpm selama 15 menit. Endapan dan cairan yang terbentuk dipisahkan. Endapan yang terbentuk ditambahkan etanol sebanyak $10 \mathrm{~mL}$ kemudian dikocok kemudian sampel dikarakterisasi menggunakan TEM. Padatan perak nanorods yang sudah dikeringkan terlebih dahulu dikarakterisasi topografi dan morfologi dan strukturnya masing-masing dengan TEM (Transmission Electron Microscope Philips XL-30) dan XRD.

\section{HASIL DAN PEMBAHASAN}

Pengaruh penambahan katalis natrium hidroksida $0,1 \mathrm{M}$ dengan variasi volume $(0,5 \mathrm{~mL} ; 1$ $\mathrm{mL}$; dan $2 \mathrm{~mL}$ ) terhadap perak nanorods diamati dengan spektrofotometer UV-vis pada panjang gelombang 300 - 900 nm ditunjukkan pada Gambar 1.

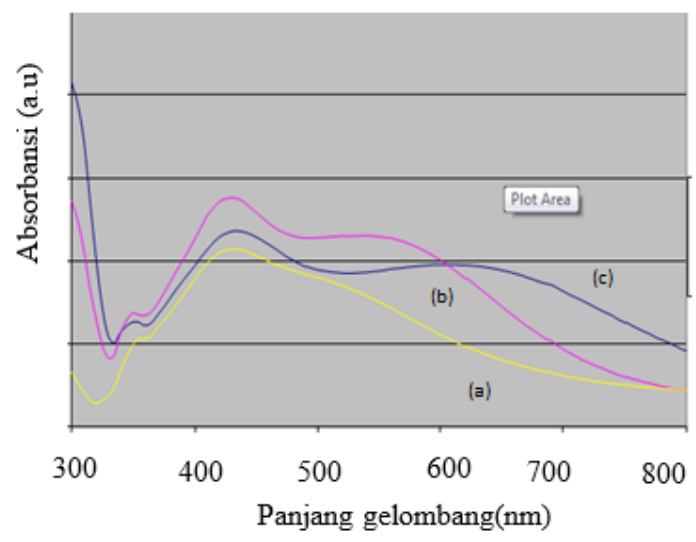

Gambar 1 Spektra UV perak nanorods dengan variasi volume natrium hidroksida (a) $2 \mathrm{~mL}$, (b) $0,5 \mathrm{~mL}$, dan (c) $1 \mathrm{~mL}$.

Pada kurva (a) kuning, (b) ungu, dan (c) biru, dan terlihat dua puncak yang menunjukkan pita plasmonik perak pada panjang gelombang $431 \mathrm{~nm}(2 \mathrm{~mL}), 433 \mathrm{~nm}(1 \mathrm{~mL})$, dan $432 \mathrm{~nm}(0,5$ $\mathrm{mL})$. Pita plasmonik longitudinal nanorods perak muncul pada panjang gelombang $580 \mathrm{~nm}(0,5$ $\mathrm{mL}), 630 \mathrm{~nm}(1 \mathrm{~mL})$, sedangkan untuk variasi penambahan natrium hidroksida $2 \mathrm{~mL}$, puncak longitudinalnya lemah, hal ini menandakan nanorods perak yang terbentuk sangat sedikit, atau bentuknya cenderung berpentuk bola. Dugaan tersebut diperkuat dengan hasil TEM pada 
Noviyanti, A. R., Hastiawan, I Akrajas

Ali Umar, A.A., Diana Eddy, D. R., Abdilah, G.
Pengaruh Surfaktan Biner Cetil Trimetil Amonium Bromida (CTAB)-Hexametilen Triamin (HMT) pada Pembentukan Perak Nanorods menggunakan Katalis Natrium Hidroksida

Gambar 2, partikel perak berbentuk bola lebih banyak dibandingkan bentuk batang (rods). Sementara diameter nanorods perak berkisar antara $21 \mathrm{~nm}-30 \mathrm{~nm}$ dan panjang berkisar antara $87 \mathrm{~nm}-112 \mathrm{~nm}$.

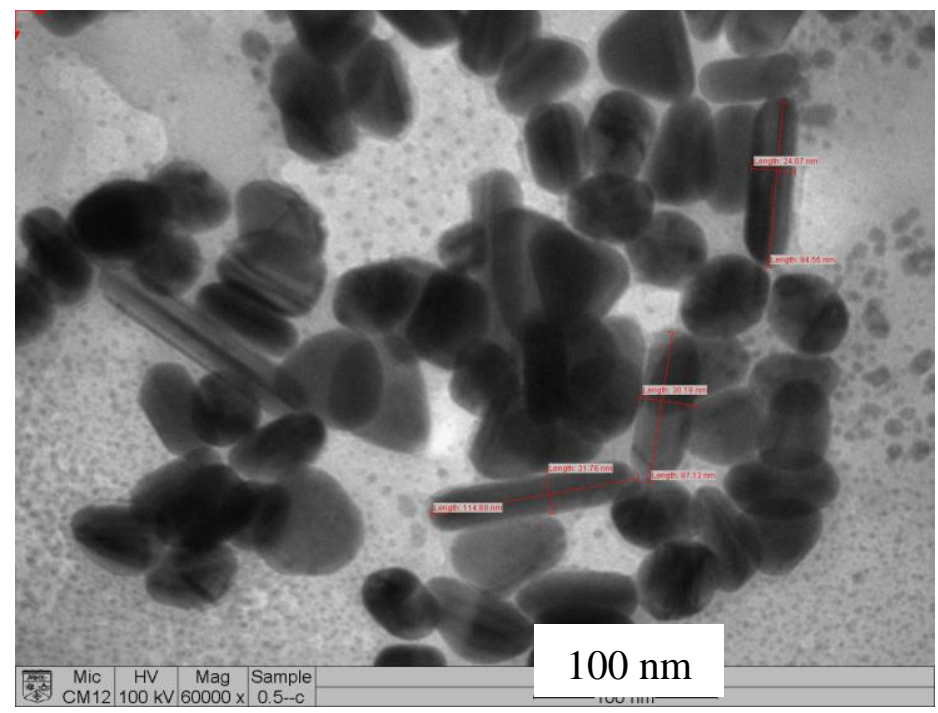

Gambar 2 Mikrograf TEM perak nanorods dengan penambahan natrium hidroksida $\quad 0,5 \mathrm{~mL}$ memiliki diameter antara $21 \mathrm{~nm}-30 \mathrm{~nm}$ dan panjang antara 87 $\mathrm{nm}-112 \mathrm{~nm}$.

Berdasarkan hasil tersebut untuk proses penumbuhan perak nanorods selanjutnya digunakan penambahan natrium hidroksida sebanyak $0,5 \mathrm{~mL}$. Sementara diameter nanorods perak berkisar antara $21 \mathrm{~nm}-30 \mathrm{~nm}$ dan panjang berkisar antara $87 \mathrm{~nm}-112 \mathrm{~nm}$.

Pengaruh surfaktan variasi konsentrasi CTAB dan HMT terhadap pembentukan nanorods perak dikontrol dengan spektra UV, ditujukkan pada Gambar 3. 
Noviyanti, A. R., Hastiawan, I Akrajas

Ali Umar, A.A., Diana Eddy, D. R.,

Abdilah, G.
Pengaruh Surfaktan Biner Cetil Trimetil Amonium Bromida (CTAB)-Hexametilen Triamin (HMT) pada Pembentukan Perak Nanorods menggunakan Katalis Natrium Hidroksida

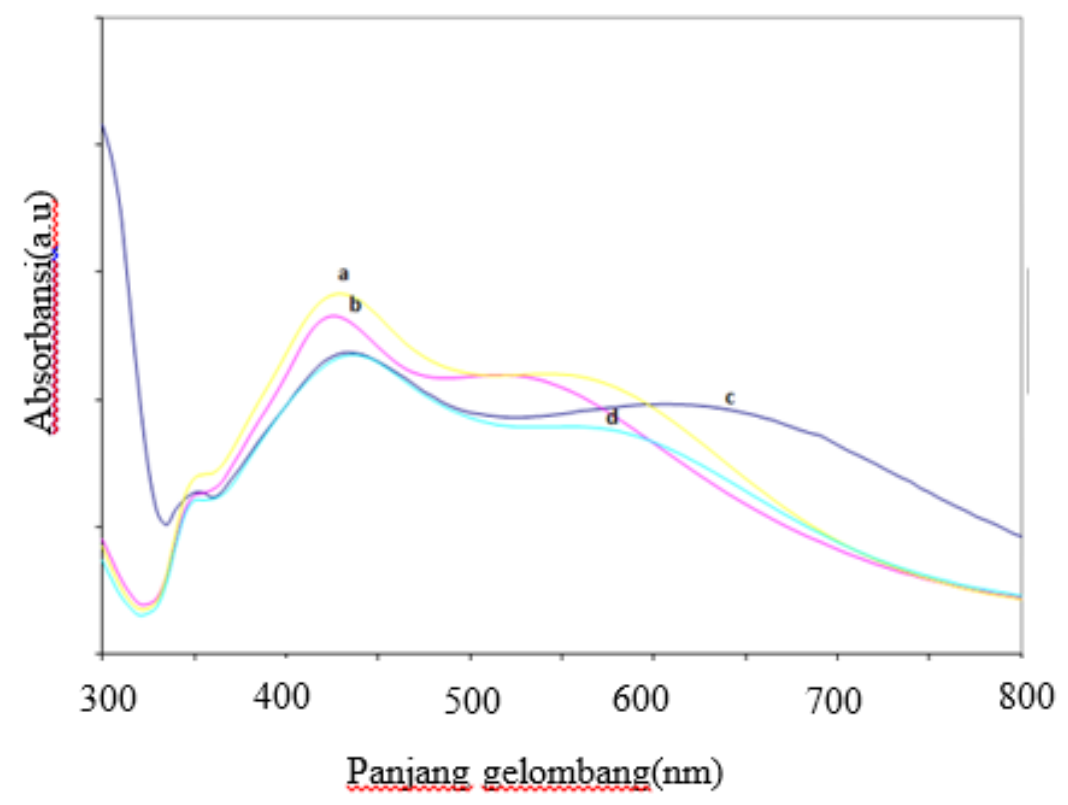

Gambar 3 Spektrum Uv-Vis larutan perak nanorods dengan penambahan 10 mL HMT dan 10 mL CTAB masing-masing konsentrasi (a) 0,15 M (b) 0,05M (c) $0,1 \mathrm{M}$ dan (d) 0,2 $\mathrm{M}$.

Pada kurva a sampai dengan d terlihat dua puncak yang menunjukkan pita plasmonik perak pada (a) $431 \mathrm{~nm}$, (b) $425 \mathrm{~nm}$, (c) $435 \mathrm{~nm}$, dan (d) 436. Puncak ini merupakan pita plasmonik transversal yang lazim untuk partikel perak yang berbentuk bola. Pita plasmonik yang terpisah pada area panjang gelombang yang panjang diakibatkan oleh pita plasmonik longitudinal dari partikel yang berbentuk rods. Pita plasmonik longitudinal muncul pada panjang gelombang (a) $570 \mathrm{~nm}$, (b)530 nm, (c) $650 \mathrm{~nm}$, dan (d) $580 \mathrm{~nm}$.

Nanorods perak yang ditumbuhkan pada larutan penumbuh dengan konsentrasi surfaktan CTAB:HMT 0,15 M : 0,15 M memiliki nilai serapan yang lebih tinggi bila dibandingkan dengan perbandingan surfaktan CTAB:HMT lainnya. Hal ini dapat diprediksikan bahwa jumlah nanorods pada sampel dengan perbandingan konsentrasi CTAB:HMT 0,15 M : 0,15 M lebih banyak bila dibandingkan dengan sampel pada perbandingan konsentrasi lainnya. Berdasarkan hasil ini untuk proses penumbuhan nanorods selanjutnya digunakan konsentrasi surfaktan CTAB dan HMT sebesar 0,15 M.

Pengaruh konsentrasi surfaktan HMT (0,05 M; 0,1 M; 0,15 M; dan 0,2 M) terhadap pembentukan perak nanorods ditunjukkan pada Gambar 4. 


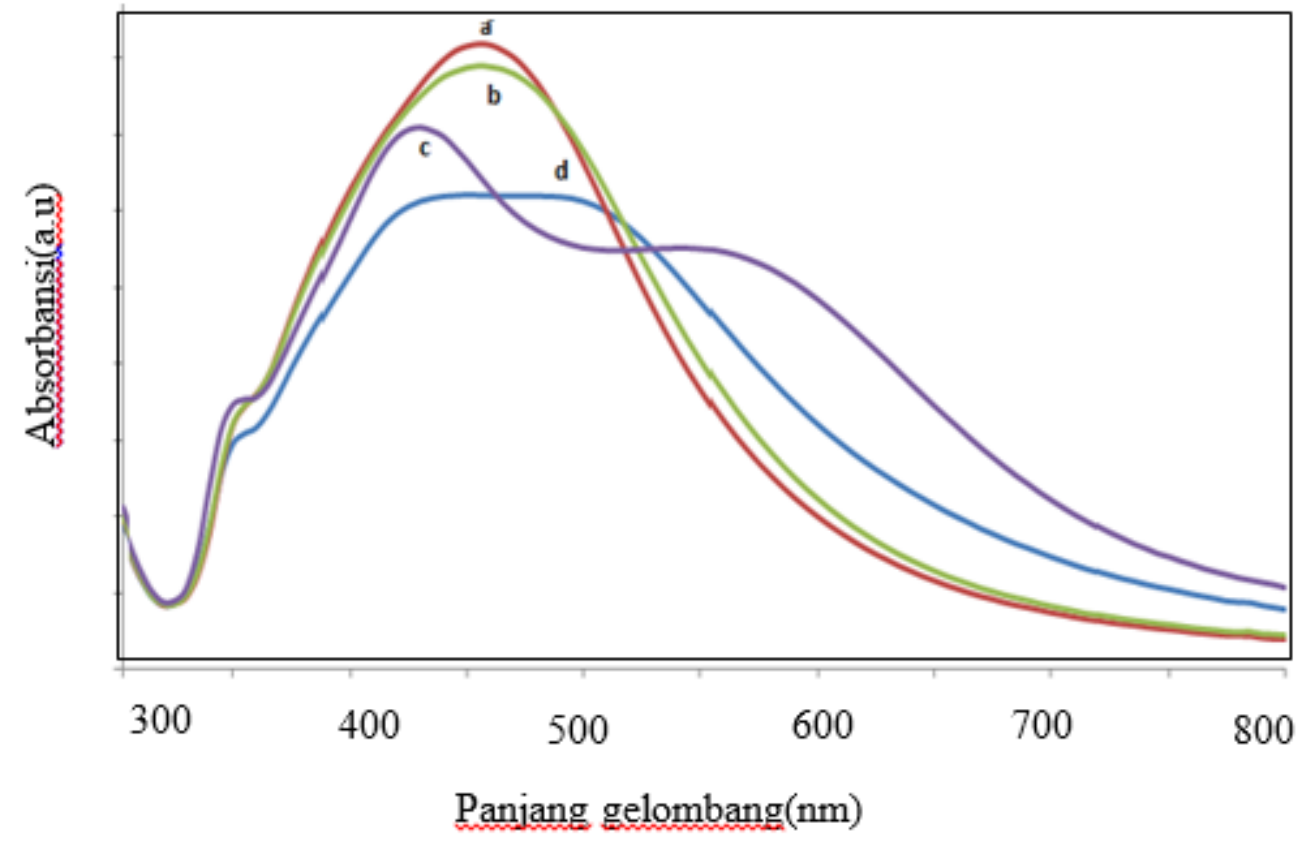

Gambar 4 Spektrum Uv -vis i larutan perak nanorods dengan penambahan 10 mL CTAB 0,15 M dengan penambahan HMT dengan konsentrasi (a) 0,1 M (b) $0,2 \mathrm{M}$ (c) $0,15 \mathrm{M}$ dan (d) $0,05 \mathrm{M}$.

Pada kurva a, b, dan d (variasi konsentrasi HMT 0,1 M; 0,2 M; dan 0,15 M ) hanya terlihat satu puncak yang menunjukkan pita plasmonik perak. Satu puncak terlihat pada (a) $450 \mathrm{~nm}$, (b) $452 \mathrm{~nm}$, dan (d) $470 \mathrm{~nm}$ yang merupakan pita plasmonik transversal yang lazim untuk partikel perak yang berbentuk bola. Karena pita yang muncul hanya memiliki satu puncak saja, maka kurva a, b, dan d tidak mengandung perak nanorods. Pita plasmonik longitudinal perak nanorods muncul pada panjang gelombang $570 \mathrm{~nm}$, hanya kurva (d) saja yang memiliki dua puncak, ini berarti bahwa perak nanorods yang terbentuk hanya pada variasi konsentrasi HMT 0,15 M saja, sehingga untuk proses penumbuhan nanorods perak selanjutnya digunakan HMT 0,15 M.

Pengaruh konsentrasi larutan CTAB $(0,05 \mathrm{M} ; 0,1 \mathrm{M} ; 0,15 \mathrm{M}$; dan 0,2 M) terhadap pembentukan nanorods perak ditunjukkan pada spectra Uv pada Gambar 4. 
Noviyanti, A. R., Hastiawan, I Akrajas

Ali Umar, A.A., Diana Eddy, D. R.,

Abdilah, $G$.
Pengaruh Surfaktan Biner Cetil Trimetil Amonium Bromida (CTAB)-Hexametilen Triamin (HMT) pada Pembentukan Perak Nanorods menggunakan Katalis Natrium Hidroksida

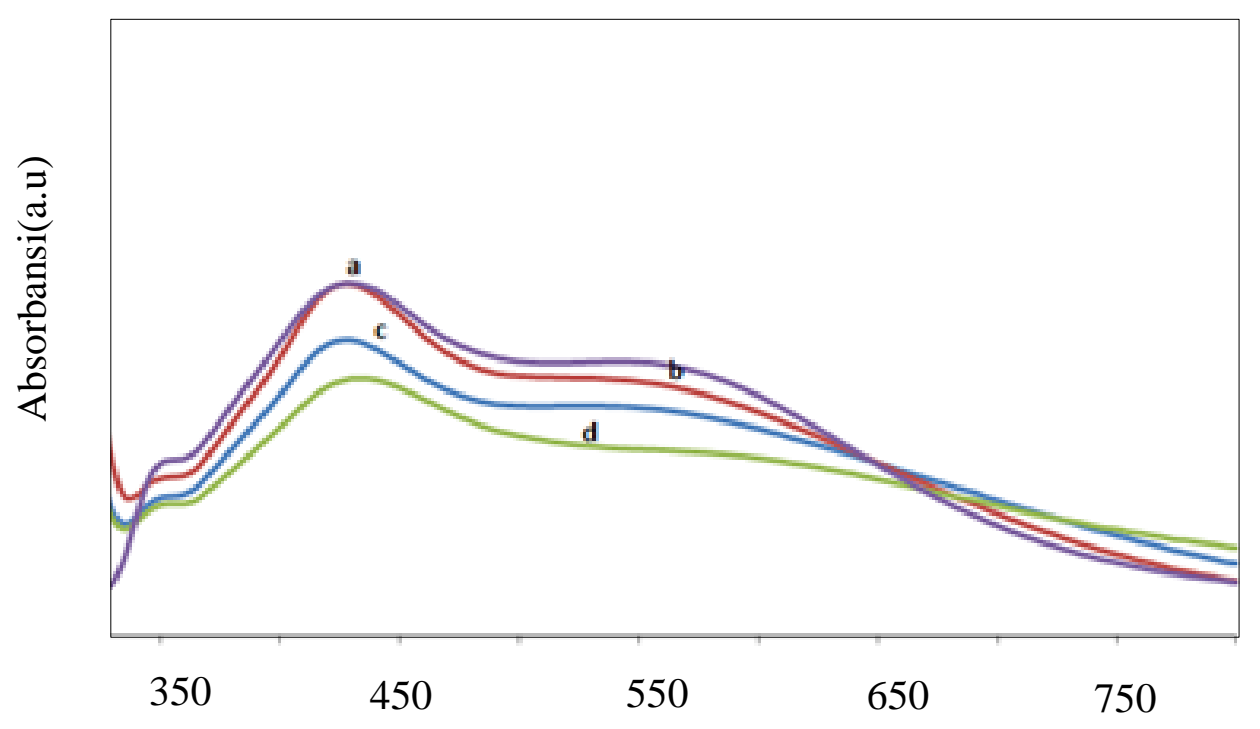

Gambar 5 Spektrum Uv tampak dari larutan perak nanorods dengan penambahan $10 \mathrm{~mL}$ HMT $0,15 \mathrm{M}$ dengan penambahan $\mathrm{CTAB}$ dengan konsentrasi (a) $0,15 \mathrm{M}$ (b) 0,1 M (c) 0,05 M dan (d) 0,2 M.

Pada kurva a sampai dengan d terlihat dua puncak yang menunjukkan pita plasmonik perak. Puncak pita plasmonik transversal terlihat pada(a) $440 \mathrm{~nm}$, (b) $442 \mathrm{~nm}$, (c) $435 \mathrm{~nm}$ dan (d) 436 $\mathrm{nm}$, puncak ini mengindikasikan partikel perak yang berbentuk bola. Pita plasmonik longitudinal muncul pada panjang gelombang (a) $580 \mathrm{~nm}$ (b) $570 \mathrm{~nm}$, (c) 570, dan (d) 600 yang mengindikasikan terbentuknya partikel perak batang.

Nanorods Perak yang ditumbuhkan pada larutan penumbuh dengan konsentrasi surfaktan CTAB:HMT sebesar $0,15 \mathrm{M}: 0,15 \mathrm{M}$ memiliki nilai serapan yang lebih tinggi bila dibandingkan dengan konsentrasi surfaktan CTAB:HMT 0,05 M : 0,15 M, 0,1 M : 0,15 M, dan 0,2 M : 0,15 M. Berdasarkan hasil ini maka untuk proses penumbuhan partikel perak nanorods dilakukan pada larutan penumbuh dengan konsentrasi surfaktan CTAB 0,15 M : HMT 0,15 M. Mikrograf TEM perak nanorods dengan konsentrasi CTAB 0,15 M : HMT 0,15 M ditunjukkan pada Gambar 6 . 
Noviyanti, A. R., Hastiawan, I Akrajas

Ali Umar, A.A., Diana Eddy, D. R., Abdilah, $G$.
Pengaruh Surfaktan Biner Cetil Trimetil Amonium Bromida (CTAB)-Hexametilen Triamin (HMT) pada Pembentukan Perak Nanorods menggunakan Katalis Natrium Hidroksida

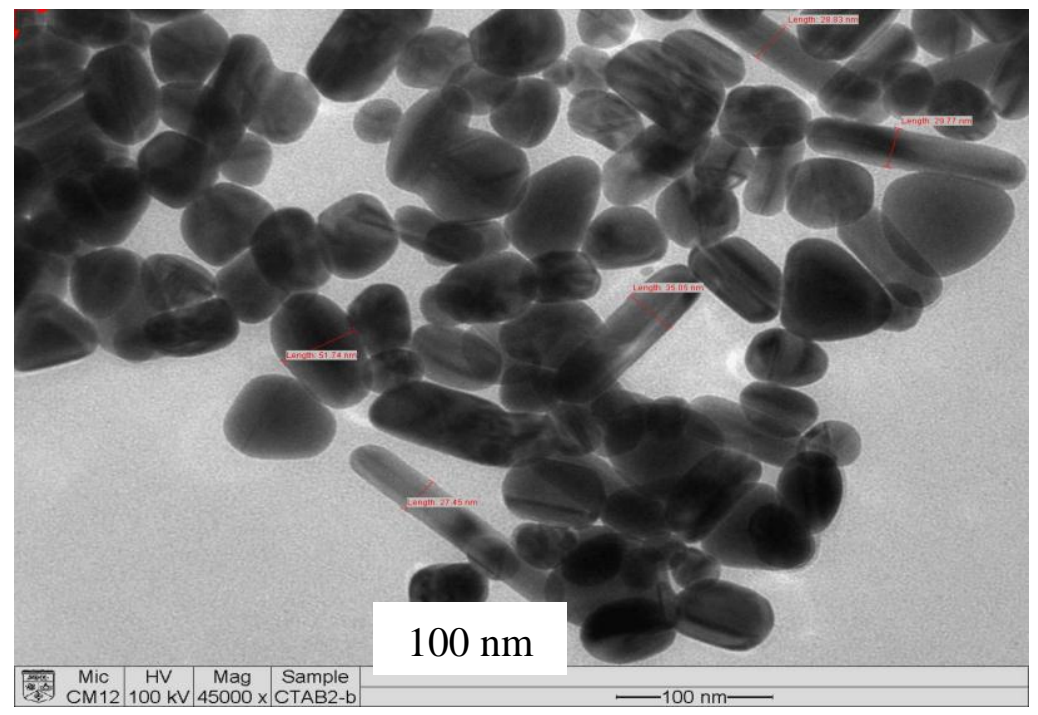

Gambar 6. Mikrograf TEM perak nanorods dengan larutan penumbuh CTAB 0,15 M : HMT 0,15 M.

Perak nanorods yang ditumbuhkan pada CTAB 0,15 M : HMT 0,15 M memiliki ukuran lebar 27,45 nm - 51,74 nm dan panjang $75 \mathrm{~nm}-150 \mathrm{~nm}$.

Karakterisasi difraksi sinar-X dilakukan untuk memastikan struktur perak partikel nano ( Error! Reference source not found.).

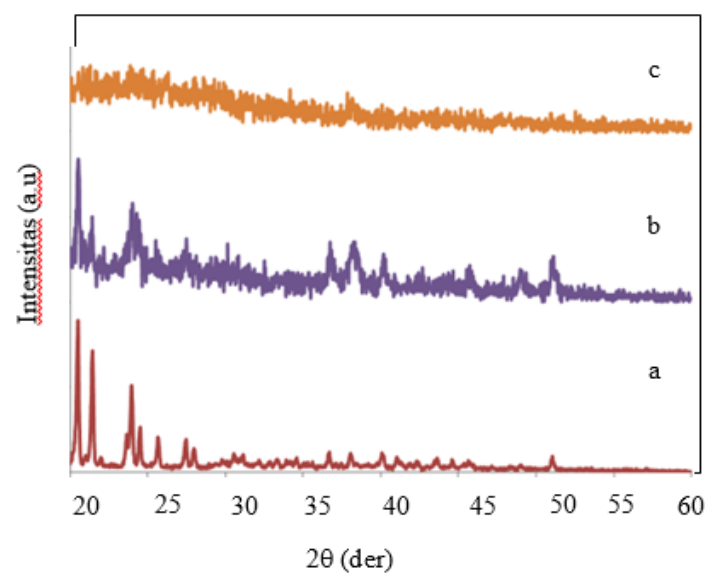

Gambar 7 Difraktogram XRD perak nanorods yang ditumbukan pada sufaktan (a) CTAB 0,1 M : HMT 0,1 M, (b) CTAB 0,15 M : HMT 0,15 M, dan (c) CTAB 0,5 M : HMT 0,5 M. 
Noviyanti, A. R., Hastiawan, I Akrajas

Ali Umar, A.A., Diana Eddy, D. R.,

Abdilah, G.
Pengaruh Surfaktan Biner Cetil Trimetil Amonium Bromida (CTAB)-Hexametilen Triamin (HMT) pada Pembentukan Perak Nanorods menggunakan Katalis Natrium Hidroksida

Pada difraktogram (a) muncul dua puncak khas perak pada sudut $2 \theta 38,10^{\circ}$ dan $44,30^{\circ}$, pada difraktogram (b) muncul puncak pada $38,10^{\circ}$ dan $44,273^{\circ}$ dan pada difraktogram (c) puncak puncul pada $38,10^{\circ}$ dan $44,30^{\circ}$, semua struktur kristalnya adalah face-center-cubic (FCC). Difraktogram (b) memiliki puncak intesitas tertinggi, hal ini menandakan partikel perak yang dipreparasi dengan surfaktan CTAB 0,15 M : HMT 0,15 M merupakan sampel dengan kandungan partikel nano perak terbanyak. Hal ini menunjukkan banwa data XRD sesuai dengan data TEM yang sama-sama menyatakan jumlah kandungan perak terbanyak pada kondisi preparasi tersebut.

\section{PENUTUP}

Partikel nanorods perak telah berhasil disintesis menggunakan metode mediasi pembenihan dengan katalis natrium hidroksida dan surfaktan biner CTAB-HMT. Kondisi optimum reaksi berlangsung pada konsentrasi CTAB 0,15 M : HMT 0,15 M dengan ukuran partikel rata-rata lebar sebesar 27,45 nm - 51,74 nm dan panjang sebesar $75 \mathrm{~nm}-150 \mathrm{~nm}$.

Berdasarkan hasil karakterisasi difraksi sinar-X partikel nanorods perak yang terbentuk memiliki struktur kristal Face Centered Cubic konsentrasi partikel perak tertinggi diperoleh dari surfaktan CTAB 0,15 M : HMT 0,15 M. Berdasarkan variasi konsentrasi surfaktan CTAB: HMT yang diamati memiliki konsentrasi yang sama yaitu 0,15 M pada pembentukan optimum nanorods perak.

\section{DAFTAR PUSTAKA}

Abdullah, M., Virgus ,Y., Nirmin., Khairurrijal. 2008 . Review: Sintesis Nanomaterial . Jurnal Nanosains \& Nanoteknologi. 1: 2.

Burrell RE, Heggers JP, Davis GJ, Wright JB. 1999. Review Efficacy of silvercoated dressings as bacterial barriers in a rodent burn sepsis model. Wounds. 11:64- 71

Brioude, A., X.C. Jiang, M.P. Pileni. 2005.Optical Properties of Silver Nanorods: DDA Simulation Supported by Experiments. Journal Physics Chemistry B 109: 13138-13142.

Cozzoli., P.D, R. Comparelli., E.Fanizza., M.L. Curri., A.Agostiano., D. Laub. 2004 .

Photocatalytic Synthesis of Silver Nanoparticles Stabilized by $\mathrm{TiO}_{2}$ Nanorods : a Semiconductor/ Metal Nanocomposite in Homogenous Nonpolar Solution. J. Am. Chem. Soc. 126: 3868-3879.

Elechiguerra, J.L., Burt, J.L., Morones, J.R., Camacho-Bragado, A., Gao, X., Lara, H.H., Yacaman, M.J. 2005. Interaction of silver nanoparticles with HIV-1. J. Nanobiotechnol., 29 (3): 6.

Gong, L., Li H., Wang, k., Hu j, Tan W. 2007. Preparation and Antibacterial activity of $\mathrm{Fe}_{3} \mathrm{O}_{4}$ Ag Nanoparticle. Nanotechnology, 18: 604-11. 
Noviyanti, A. R., Hastiawan, I Akrajas

Ali Umar, A.A., Diana Eddy, D. R.,

Abdilah, G.
Pengaruh Surfaktan Biner Cetil Trimetil Amonium Bromida (CTAB)-Hexametilen Triamin (HMT) pada Pembentukan Perak Nanorods menggunakan Katalis Natrium Hidroksida

Moores, A., Goettmann, F. 2006. The plasmon band in noble metal nanoparticles: An introduction to theory and applications, New J. Chem., 30:1121-1132.

Percival, S.L., Bowler, P.G., Dolman, J. 2007. Antimicrobial activity of silver-containing dressings on wound microorganisms using an in vitro biofilm model. Int. Wound. J. 4: 186191.

Wijnhoven, S.W.P., Peijinenburg, W.J.G.M., Herberts, C.A., Hagens, W.I., Oomen, A.G., Heugens, E.H.W., Roszek, B., Bisschops. 2009. Nanosilver : A Review of Available data and Knowledge Gaps in Human and Environmental Risk Assessment. Nanotoxicology .3 (2): 109-138. 